\title{
異なる生産関数による社会資本ストックと 民間資本ストックの限界生産性評価に関する研究
}

\author{
信州大学 小山 健*1 \\ 信州大学 高瀬 達夫*2 \\ 愛知県 伊藤 仁 $*^{3}$
}

By Ken Koyama, Tatsuo Takase, and Jin Ito

社会厚生にとって公共財の最適供給量について議論することは必要であり, 限られた条 件が満たされる場合にはその最適量が理論的には求められることは既知である ${ }^{1), 2)}$. しか しながら現実の社会はその条件を満たすことはなく従って公共財は過少供給になりやす い. 市場の失敗といわれるもののうちの一つである. 公共財のほとんどは公共事業を通し て供給されると考えて良い。

公共事業による公共投資の結果は社会資本としてストックされ，民間部門の生産性向上 や生活環境の向上に寄与している。このように社会資本は社会厚生に必要と考えられるが 現在わが国ではその投資について疑問が呈されている. 国の負債が原因となった，限られ た投資額に効率性が求められるからと考えられる. 本研究では社会化資本ストックの限界 生産性を計測することで，もう一単位の公共事業の必要性を計測することにした。

【キーワード】公共事業, 社会資本ストック，生産性評価，限界生産性

\section{1. はじめに}

近年, 公共事業への風当たりは厳しいものがある. 環境問題への配慮, 財政状況の悪化, 公共事業受注 の際の談合の問題などの理由の中で, 社会資本投資 が今以上に必要かを指摘する声がある。このような 批判は小林がすでに指摘しているように ${ }^{3)}$, 「社会資 本が生産性の効率に寄与していないことを主張して いるのではなく，すでに社会資本が十分あるため,

これ以上社会資本を増加させても, 総生産の増加に つながらないのではないか」, との批判であると著者 らも考えたい。

わが国の状況は，少子・高齢化，人口減少といっ た社会構造の変化と世界的グローバリゼーションの 進展の中, より市場化と競争化により, 地域・産業 間の格差が拡大したといわれている。 それは，従来

*1 工学部土木工学科 $026(269) 5281$

*2 工学部土木工学科 $026(269) 5307$

$* 3$ 愛知県庁
の右肩上りの成長率を前提とした財政主導による地 域間の再配分と調整で補完するというシステムの維 持が困難になってきているとためだと考えられる. 一方で, 市場では供給過少となる公共財としての社 会資本の生産性と効率を定量的に把握することは今 後の社会資本整備には重要な課題であると言える.

社会資本を公共財とみなした場合の供給の効率 性については，乙の限界代替率の合計と限界変形率 の等価性を見ることで可能となるが，社会がパレー 卜最適になっているかあるいは例えばクラーク税 ${ }^{2)}$ のような税負担についてはどうするかといった状況 を考慮する必要が生ずる。また, 社会資本は生産の 効率化のみに資するだけでなく, 国土の保全, 生活 環境の改善など, 国民生活の広い範囲にわたって影 響を及ぼすがそれらの全体の評価はここでは荷が重 過ぎる，したがってここでは，わが国に現存する社 会資本ストック効果について，生産性の効率評価に 限定しそれの弾力值と限界生産性という尺度で評価 するものとした。 
本研究では, いくつか存在する生産関数のなかで は一般的に多く使用されているコブ=ダグラス型

（CD 型）生産関数と, トランスログ型（TL 型）生 産関数を採用し，わが国の 1975 年から 2000 年にお ける GDP と都道府県ごとの社会資本ストックと民 間資本ストックのクロスデータから弾力值と限界生 産性の值を求め, 生産関数により得られる結果の違 いについて調べた。ささらに時系列データを用いて, 都道府県毎の限界生産性の計測も行った。

本研究で用いた社会資本と民間資本ストックデー

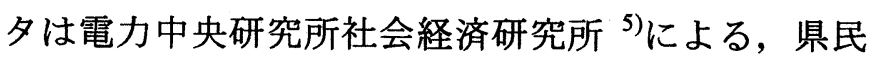
経済計算年報，国勢調査および公共工事着工統計等 を用いて整備された昭和 45 年（1970） から平成 13 年 (2002) までの 47 都道府県別のものである. デー 夕を具体的に目的区別で大別すると 1 . 農林水産基 盤（農林漁業施設），2. 産業基盤（道路一国県道, 道路-4 公団+地方道, 港湾 - 空港), 3. 運輸 - 通 信基盤（旧国鉄・電電公社, 鉄道・郵便業), 4. 生 活基盤（道路一市町村道, 都市公園 - 自然公園 -下 水道 -上水道, 社会保険 - 社会福祉施設 - 学校 - 病 院）であり一般行政資産および治山・治水施設は除 いて計測されている. なお，民間資本ストックデー 夕は製造業と非製造業からなっているが，本研究で はそれらを合計したものとみなした. データ整備対 象についてはここでは省略する.

\section{2. 既存研究の整理と本研究の位置付け}

\section{1 既存研究について}

社会資本の生産性に関する研究は，これまで膨大 な研究がなされてきている. 先行研究として代表的 なものとして D.A.Aschuer ${ }^{4}$ の研究がある.そこでは $\mathrm{CD}$ 型生産関数を用い, 生産効率に関し計測した結 果, 高速道路, 一般道路, 上・下水道システムのよ うな非軍事構造物である社会資本が生産性の改善に はより有効であるとの提案がされている．わが国に おいても，社会資本の生産性や経済成長効果に関す る数多くの研究成果が蓄積されている，その中でも 江尻ら ${ }^{6)}$ は内外の研究についてそれらの代表的研究 について膨大な数のレビューを実行しておりこの種 の後発研究には欠かせないものとなっている.

また，社会資本の類型によっては，ある地域（都
道府県や州等）の社会資本は近隣地域の生産性をも 高める効果，いわゆる「スピルオーバー効果」を持 つので，モデルの構成上その処理をどのようにする かといった問題がある。これに関して塚井ら ${ }^{7)} は$, 社会資本のスピルオーバー効果と生産性を計測し, 知識の階層的なスピルオーバーと生産要素の双方向 的なスピルオーバー効果の存在を明らかにした。こ れら 2 つ論文には数多くの文献が掲載されている のでそれらを参照されたい. 以上から本研究では, これ以上更なるレビューの必要性は認めないので, 本文で特に参考とした先行論文 ${ }^{8)-16)}$ について最小限 について載せることにした。

以上のように, 先行研究において様々な方法で社 会資本の生産性が計測されてきた。しかし，小林 ${ }^{3)}$ は社会資本の生産性に関する議論の信憑性を議論す るためには，その前提となっている社会資本ストッ クデータの信頼性を吟味することが不可欠である, と指摘している.

\section{2 社会資本ストックデータの問題点}

社会資本ストックの測定方法としては(1)PI 法, （2）BY 法，(3) PS 法があり，わが国の社会資本ストッ クデータは, 1970 年の国富調査をベンチマークとし て,その後の社会資本を 47 年サドンデス方式による PI 法で積み上げたものである ${ }^{3)}$ が, 耐用期間 47 年が 過ぎても除去されずにストックとして現在もそのま ま計測されているものがかなりあり, 小林ら ${ }^{3)}$ は現 実のストック額よりも2 倍程度も膨らんだ結果にな っている可能性がありその影響が社会資本ストック の見かけ上の生産性低下要因となっているのではと 指摘している.

これに関しては例えば, 長野県内の市町村で社会 資本ストックの計測がまとまって複数年されていた ところは, 平成 16 年 4 月の時点で大町市 1 市だけで あった. したがってインフラ会計の重要さが指摘 ${ }^{17)}$ される所以となっているが，財政状況の悪かった岩 手県岩泉町が先駆的に平成 15 年度について普通会 計のバランスシートを作成した．今後このような傾 向はますます多くの市町村で進展が期待され適正に ストックの除去が実施されると，公共投資に対する 生産性が正当に評価されることにもつながるものと 期待される。 


\section{3 本研究の位置付け}

本研究では電力中央研究所経済研究所が BY 法 （基準年次法）を適用して推計したデータ(2006 年 改訂版 $)^{5)}$ 用いることとした。この BY 法は基準年 の資本ストック額に対し，その後の毎年の投資額お よび除却額の系列を加減していく方法であり，今回 用いるデータでは基準年を 1970 年としている.この データは昭和 45 年〜平成 14 年の期間における社会 資本ストック，民間企業ストックおよび投資のデー タについて整備されている.これらのデータの推計 方法については電力中央研究所社会経済研究所 ${ }^{5} お$ よび土居 ${ }^{18)}$ に詳しい。

なおここで用いた社会資本ストックの推計式は

$$
K_{t}=K_{t-1}+I_{t}-D_{t}
$$

となっている。

ここで， $K_{t}, I_{t}, D_{t}$ はそれぞれ投資ストッ ク額，投資額，除去額である。除去額 $\boldsymbol{D}_{1}$ は ガンマ分布のを用いて平均耐用年数 30 年, 40 年後の残価率 $10 \%$ で確率的に除去している.

したがってストックのある程度は除去されて いるものと考えられ 2.2 で述べられた問題点 を幾分かは是正できているものと考えられる。

\section{3. 社会資本の生産性の計測について}

\section{1 コブ=ダグラス型生産関数}

社会資本の生産を計測する一般的な方法として, 生産関数を用いる方法がある。ここでは, 社会資本 ストックと民間資本ストックの弾力值を求めること から生産関数としてもっとも簡単で広く使われてい るCD型生産関数を用いることにした。

ただしわが国では失業率には大きな変化が見られ ないことから, 労働力を一定と仮定とすることとし， 次式のような労働力を考慮に入れない生産関数を用 いることとした。

$$
\boldsymbol{Y}=\boldsymbol{A} \boldsymbol{K}^{\beta} \boldsymbol{G}^{\gamma}
$$

ここで， $Y$ は総生産額， $K$ は民間資本ストック， $G$ は社会資本ストック， $A$ はパラメータである。こ こで， $\beta, \gamma$ はそれぞれ，民間資本ストックと社会 資本ストックの生産弾力值であり，民間資本ストッ ク $K$ がおよび社会資本ストック $G$ が 1 \%増加した 時の総生産の変化率を表している.

\section{2 トランスログ型生産関数}

本研究では $\mathrm{CD}$ 型生産関数を特殊形にもつ $\mathrm{TL}$ 型 生産関数も用いた. TL 型生産関数は以下のように表 される。

$\ln Y=\alpha_{0}+\alpha_{L} \ln L+\alpha_{K} \ln K+\alpha_{G} \ln G$

$+\frac{1}{2} \gamma_{L L}(\ln L)^{2}+\frac{1}{2} \gamma_{K K}(\ln K)^{2}+\frac{1}{2} \gamma_{G G}(\ln G)^{2}$

$+\gamma_{L K} \ln L \ln K+\gamma_{K G} \ln K \ln G+\gamma_{G L} \ln G \ln L$

ここで, $Y$ は総生産額， $L$ は労働投入量（就業者と 労働時間を乗じた值), $K$ は民間資本ストック, $G$ は 社会資本ストック, $\alpha_{i}, \alpha_{i i}, \gamma_{i j}(i, j=L, K, G)$ は未知 パラメータである.

ここで,

$y=\ln Y, a=\alpha_{0}, x_{1}=\ln L, x_{2}=\ln K, x_{3}=\ln G$,

$\boldsymbol{x}_{4}=\frac{1}{2}(\ln L)^{2}, \boldsymbol{x}_{5}=\frac{1}{2}(\ln K)^{2}, \boldsymbol{x}_{6}=\frac{1}{2}(\ln G)^{2}$,

$x_{7}=\ln L \ln K, x_{8}=\ln K \ln G, x_{9}=\ln G \ln L$

とおくと，

$y=\alpha+\alpha_{L} x_{1}+\alpha_{K} x_{2}+\alpha_{G} x_{3}+\gamma_{L L} x_{4}+\gamma_{K K} x_{5}$

$+\gamma_{G G} x_{6}+\gamma_{L K} x_{7}+\gamma_{K G} x_{8}+\gamma_{G L} x_{9}$

となる. 式 (5) を重回帰分析することにより未知パ ラメタを求めたが，3.1 同様 $L$ 一定と仮定した.

\section{4. クロスセクションデータによる全国レベルの計測}

\section{1 弾力值}

1975 2000年の5年ごとの各都道府県をベースと するクロスセクションデータに基づいて弾力值を求 め全国平均したものを図1〜4にのせた. 図1,3は生産 関数ごとの社会資本の生産弾力值を示した。これか ら1975年の弾力值は高かったものの徐々に減少し, 1990年以降は0.2程度になっている.また図 2,4 の民 間資本の生産弾力值は，1975年は0.52 0.45 と低か つたものの, 1985 年以降 $0.7 \sim 0.8$ と高い数值を維持 している．民間の弾力値はわが国のこの間の経済の 好調を示しているものと考えられる.次に $2 つ の$ 関数 間の結果を比較してみると，民間資本の弾力値はす べての年代でほぼ同じ值となったが，社会資本の弾 力值に関しては，長期的な傾向は似ているものの， 1975年と 1980年ではCD型生産生産関数を用いたほ 


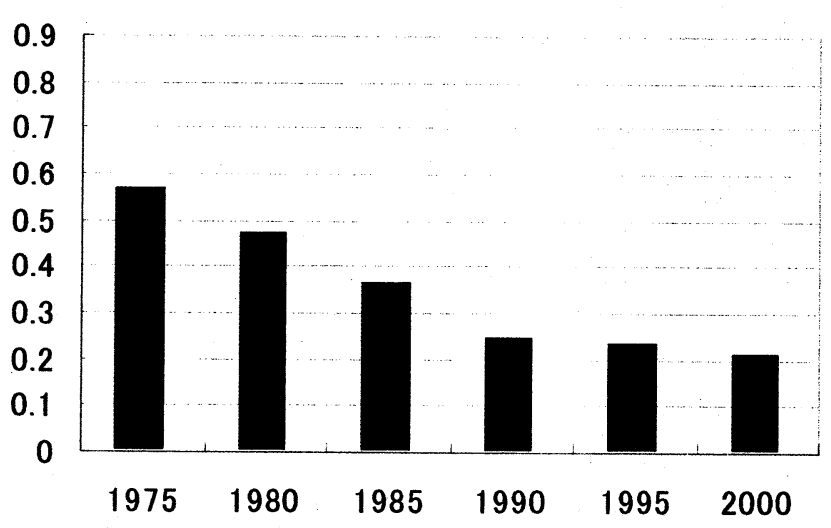

図 1 社会資本の弾力值 (CD 型)

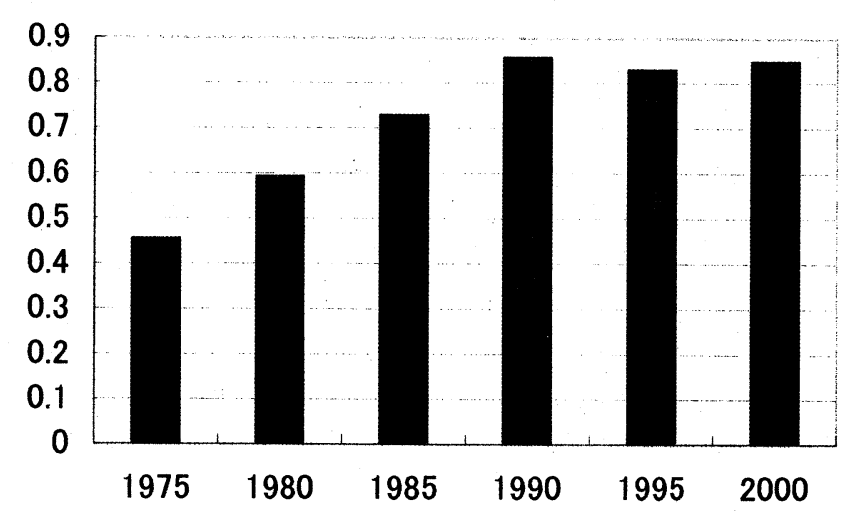

図 2 民間資本の弾力值（CD 型）

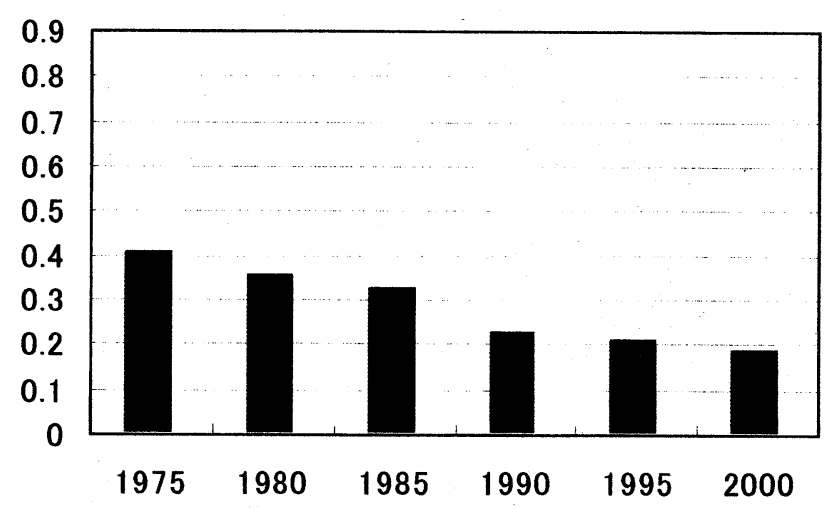

図 3 社会資本の弾力值 (TL 型)

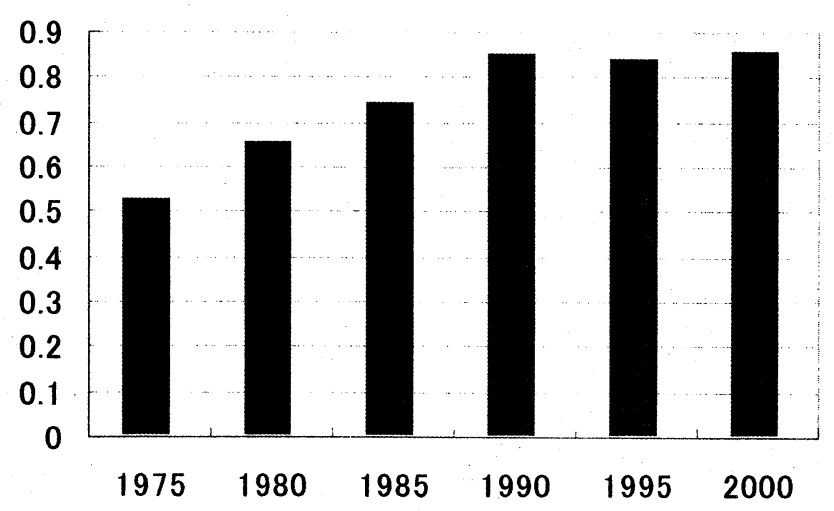

図 4 民間資本の弾力値（TL 型）
うが大きな值を示した。この原因として,いま弾力值 を $\tau$ と表すと, $\mathrm{CD}$ 型では $\tau=\gamma$ （一定）となり, $\mathrm{TL}$ 型では $\tau=\alpha_{G}+\gamma_{G G} \ln G+\gamma_{K G} \ln K$ となる. 以上か ら TL 型では都道府県の $\boldsymbol{G}, \boldsymbol{K}$ の影響を受けることか ら差が生じたものと考えられる。

\section{2 限界生産性}

社会資本ストックの弾力值 $\tau$ は, 社会資本ストッ クが本来有する総生産増加のパフォーマンスを数值 化したものである．これでは，投資額がそれぞれで 異なったまま総生産の増加額を比較するということ になり, 生産力効果の把握は直ちにはできない。そ こで, 限界生産性という概念を考える。

限界生産性の定義は, 追加的な投入物 1 単位によ り生じる生産の増加分をいい, 社会資本ストック額 が 1 単位増加した場合の総生産の増加額 $\Delta \boldsymbol{Y} / \Delta \boldsymbol{G}$ で

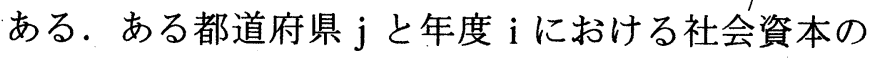
限界生産性 $\mathrm{MP}_{\mathrm{G}}$ は以下と表される。

$$
\boldsymbol{M P}_{G}=\tau \times \frac{\boldsymbol{Y}}{\boldsymbol{G}_{i j}}
$$

図 5,7 は, 各都道府県の $\boldsymbol{M} \boldsymbol{P}_{G}$ の変化を 1975 年か ら 5 年ごとの平均值を示している.この図によると, 1975 年〜80 年は全国的に高い值を示している.特に 関東圈や東海道にあたる県や瀬戸内海に面する都道 府県が高い值を示しているが, 経年とともに $\boldsymbol{M} \boldsymbol{P}_{\boldsymbol{G}}$ は 全国的に低下している. 現在にわたって $\boldsymbol{M P}_{\boldsymbol{G}}$ が減少 している大きな原因の一つは，一般にバブル経济崩 壊とされている. しかし今回の研究より, バブル経 済の最中の 1985 年から $\boldsymbol{M} \boldsymbol{P}_{\boldsymbol{G}}$ の低下が始まり, 日本 経済がバブル末期にあった 1990 年においては,すで に全国的に $\boldsymbol{M P}_{\boldsymbol{G}}$ は著しく低下していたのではとの 疑問がでる。

また生産関数による違いを見てみると, $\mathrm{CD}$ 型と TL 型ともに全国的な低下傾向がみられるが, TL 型 では地方はこの 30 年を通して景気に良し悪しにか かわらず，あまり生産性に変化がないことがわかっ た. 次に, 1975 年〜2000 年の 5 年ごとの民間資本 限界生産性 $\left(\boldsymbol{M P}_{\boldsymbol{K}}\right)$ の平均值を図 6,8 に示した. $\boldsymbol{M P}_{\boldsymbol{K}}$ は $\boldsymbol{M P}_{\boldsymbol{G}}$ とは大きく違ったパターンとなっているこ とが分かる， $\boldsymbol{M P}_{\boldsymbol{G}}$ が経年減少を続けたのに対し， $\boldsymbol{M P}_{\boldsymbol{K}}$ は年々増加し, 1990 年にピークとなる值を 

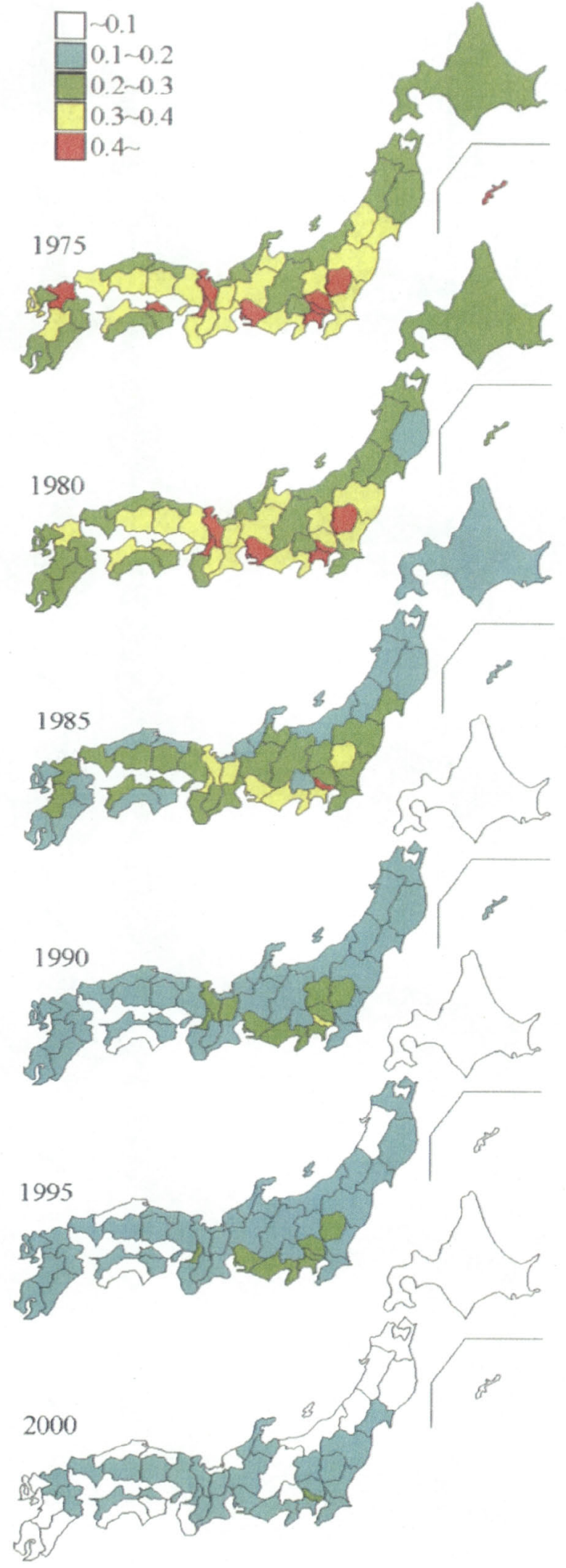

図 5 社会資本の限界生産性（CD 型）

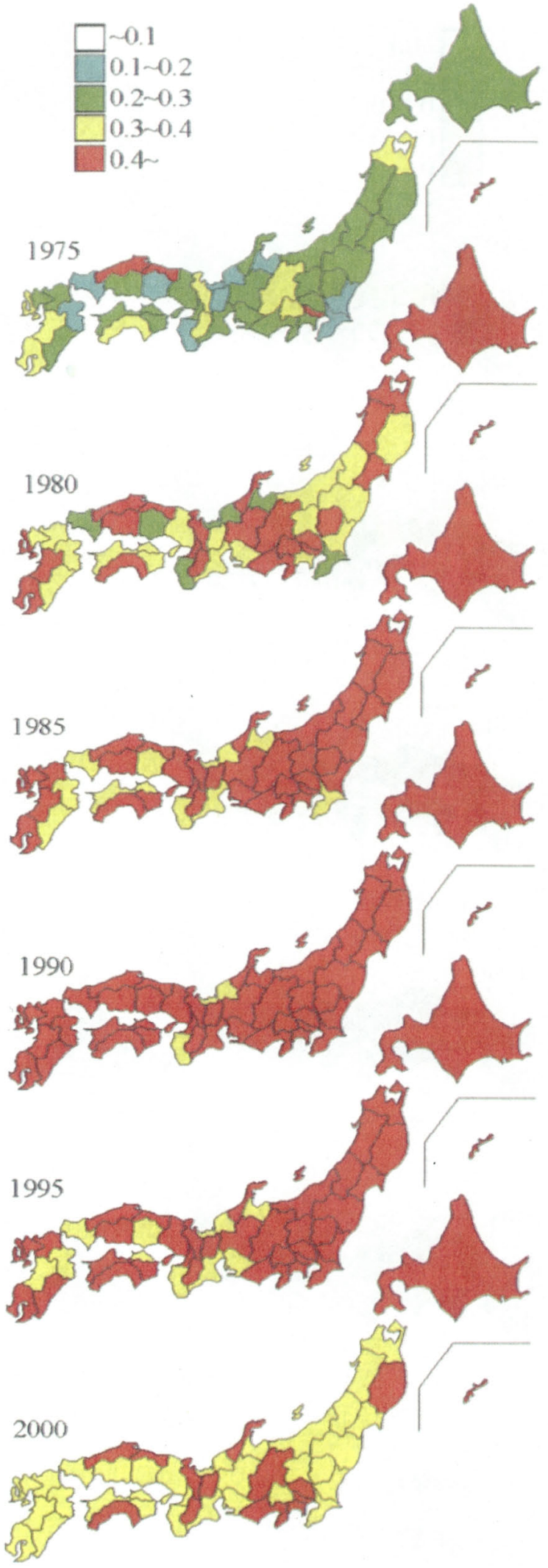

図 6 民間資本の限界生産性（CD 型）
示すも, 以後は高い值を保っている. 地域間の変化 の差をみてみると, 1975 年〜1985 年まではそれぞれ の地域で差が見られたものの, 1990 年以降は全国的
に地域閒差が小さくなっていることが分かる。また 生産関数による違いを見てみると, TL 型では 2000 年で大きな值を示している地域が, 関東・東海・近 


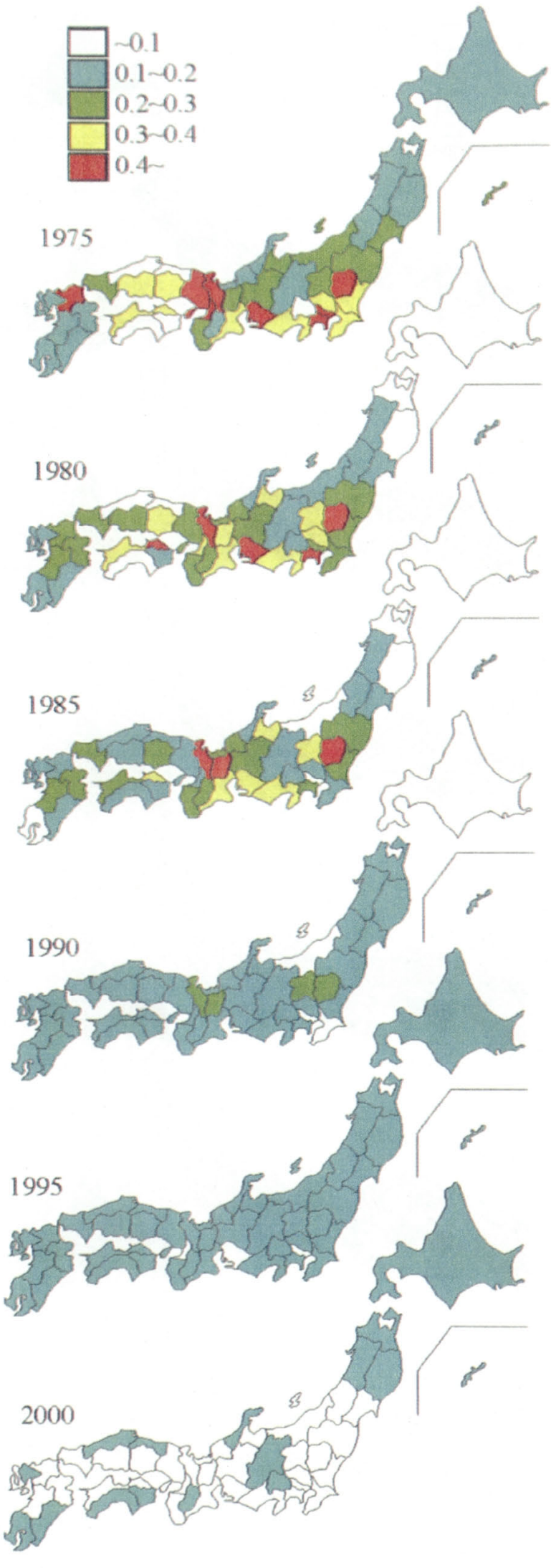

図 7 社会資本の限界生産性（TL 型）

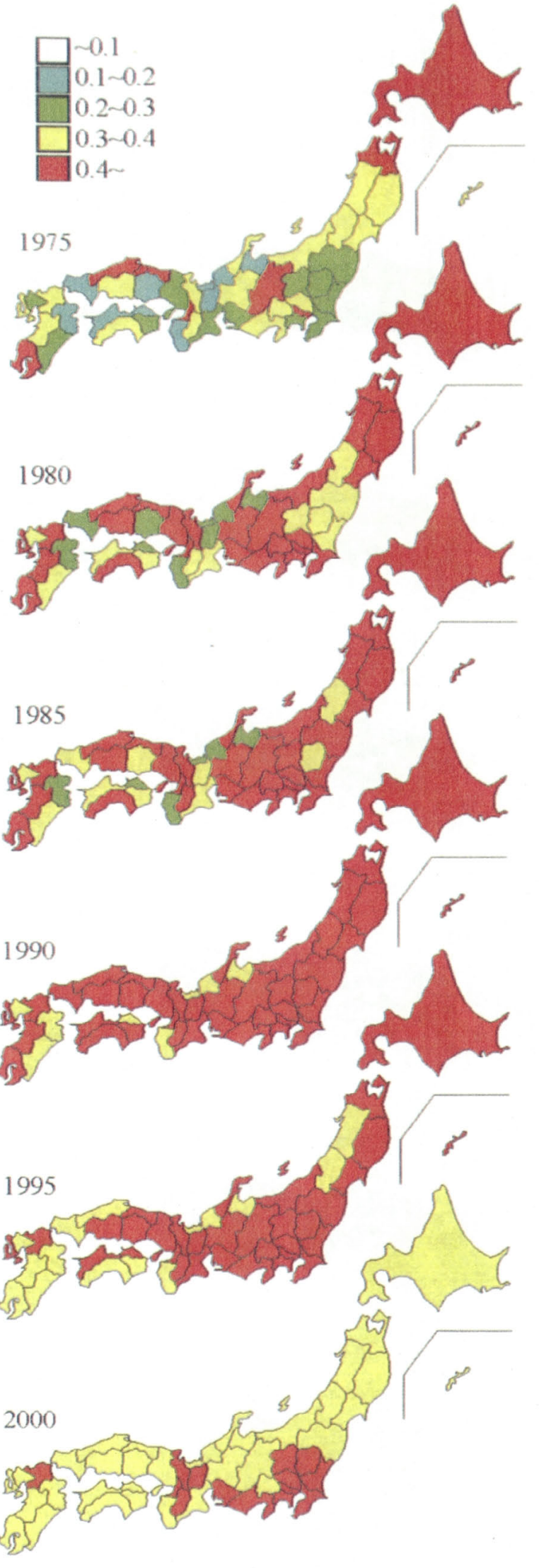

図 8 民間資本の限界生産性（TL 型）
畿・福岡という大都市圈のみであるという顕著な結 果が表れた。全体的に見てみると $\mathrm{CD}$ 型の生産関数
を用いたほうが，值が多少大きくなっているが，值 の性質を考えると過大評価は禁物であり，結果とし 


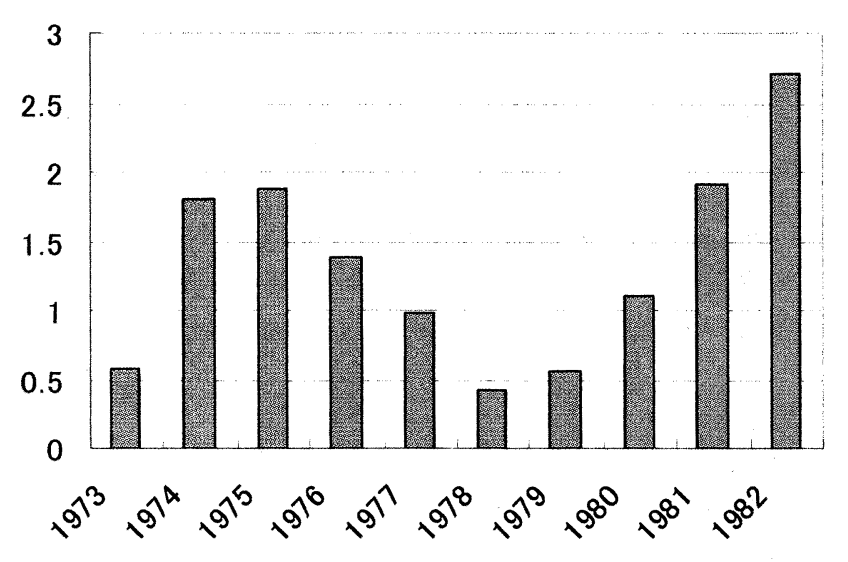

図 9 愛知県の社会資本限界生産性（1973～1982 年）

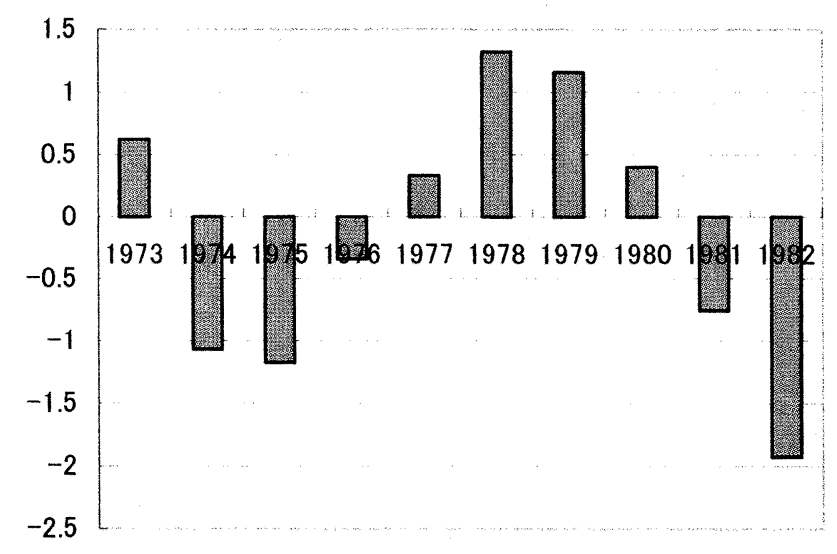

図 10 愛知県の民間資本限界生産性（1973～1982 年）

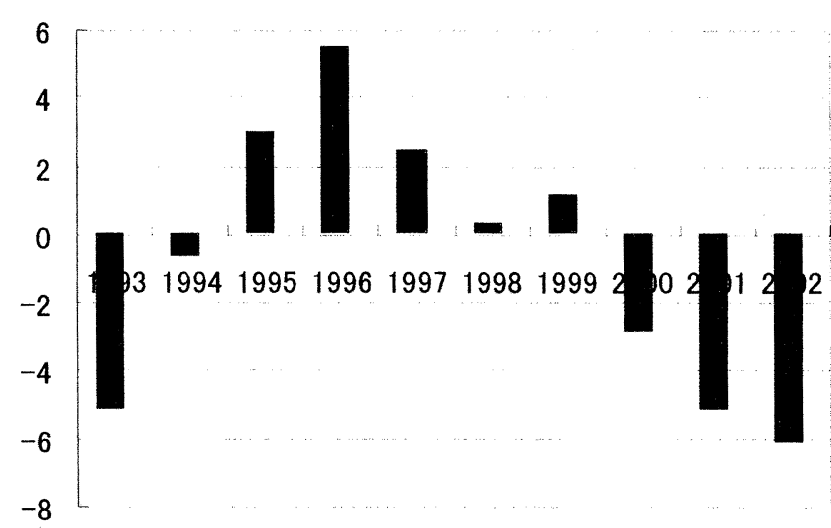

図 11 愛知県の社会資本限界生産性（1993 2002 年）

て TL 型が控えめな分,評価については好ましいと考 えられる。

ここまでクロスセクションデータに基づいて全国 レベルにおいて弾力値, 限界生産性を算出すること によって，日本全体における社会資本の効果を見て きた。しかし，ある年度のそれぞれの都道府県にお ける限界生産性は, 地域間によるスピルオーバーす

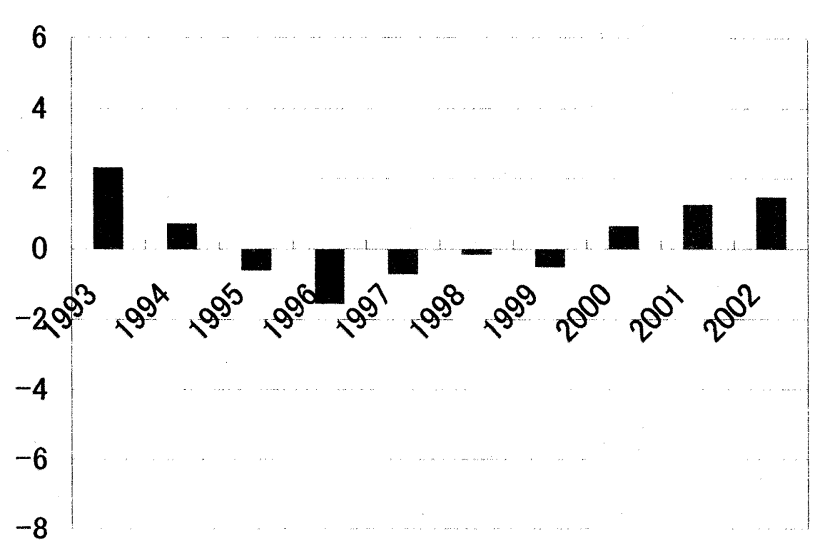

図 12 愛知県の民間資本限界生産性（1993 2002 年）

る効果が無視されている可能性が考えられる，そこ で，次章では，時系列データに基づいた各都道府県 レベルによる計測をし，各都道府県を個別に計測し て,社会資本ストックの効果を見ていくこととする.

\section{5. 時系列データによる都道府県別生産性の計測}

ここでは，時系列データに基づいた都道府県レベ ルでの社会資本の弾力值と限界生産性の計測をして いく. 計測期間としては, 1973〜1982 年, 1983 1992 年, 1993 2002 年の 10 年ごとの 3 期間である。 た だし，民間資本ストックの非製造業としてのデータ が 1975 年以降しかないため，1973〜1982 年の計測 では，製造業の民間資本ストックしか計測していな い. また時系列データに基づいて計測するため，デ 一夕数が少ないので $\mathrm{F}$ 検定， $\mathrm{t}$ 検定などにより適合 したと思われるモデルの数は非常に少なかった。こ こでは適合した例の一つとして愛知県の限界性につ いて示すこととした。なお計測には TL 型の生産関 数を用いている.

愛知県におけるバブル経済期を除いた 1973〜 1982 年の $\boldsymbol{M P}_{\boldsymbol{G}}$ と $\boldsymbol{M} \boldsymbol{P}_{\boldsymbol{K}}$ を図 9,10に，1993〜2002 年 の $\boldsymbol{M} \boldsymbol{P}_{\boldsymbol{G}}$ と $\boldsymbol{M} \boldsymbol{P}_{\boldsymbol{K}}$ を図 11,12 に示した。 $\boldsymbol{M} \boldsymbol{P}_{\boldsymbol{G}}$ は 1970 年代は毎年正の值を示しているが 1990 年代は $\boldsymbol{M} \boldsymbol{P}_{\boldsymbol{K}}$ 同様に年によって大きく変化していることがわかる. 年ごとの変化は致し方ないにせよ, 2000 年以降 3 年 連続 $\boldsymbol{M} \boldsymbol{P}_{G}$ が大きな負の值を示していることから, 愛 知県に関する限り今後の社会資本投入のあり方に注 意する必要があると考えられる。 
また CD 型生産関数でも TL 型生産関数同様, 社 会資本と民間資本の限界生産性のが逆の值をとる結 果となっている点にも注意する必要がある.

\section{6. まとめ}

本研究では, 全国都道府県別ストックデータから, $\mathrm{TL}$ 型生産関数を用いて社会資本の弾力値, 限界生産 性を計測し, $\mathrm{CD}$ 型生産関数と比較しながら，社会 資本ストックの総生産に対する効果分析を行った. 結果を見ると, 社会資本の弾力值, 限界生産性は経年 とともに減少しているが，民間資本の弾力值，限界 生産性は地域によっては高い値を維持している事 がわかった。これは社会資本ストックが蓄積された 効果とも考えられやはり必要な公共投資は持続し て実施すべきものと考えられる．今後は，より精度 の良い社会資本の生産性を計測するために，現存す る社会資本ストック額を再評価し，今後発生する社 会資本ストックの除却, 減価償却をインフラ会計と して適切に記述していくことが地方財政の健全化 にも必要な処置と考えられる.

\section{【参考文献】}

1)例えば J.E. スティグリッツ：公共経済学 [第 2 版］

（上）公共部門·公共支出, 東洋経済新報社, 2003.11.

2)竹内信仁編著 : スタンダード財政学, 中央経済社, 2005.4. ほか多数

3）小林潔司:土木事業のマクロを考える, 土木学会誌, vol.88 No1, pp.42-45,2003.1.

4)例えば代表的に Aschauer,D.A: Is public expenditure productive?, Journal of Monetary Economics, Vol23, pp.177-200, 1989.

5）（財）電力中央研究所社会経済研究所, 2006.5. http://criepi. denken. or. jp/jp/serc/index. html

6）江尻良，奥村誠・小林潔司：社会資本の生産性と経 済成長：研究展望, 土木学会論文集 No.688/IV-53, pp.75-87，2001。

7）塚井誠人・江尻良・奥村誠・小林潔司：社会資本の 生産性とスピルオーバー効果, 土木学会論文集 No.716/IV-57, pp.53-67, 2002。

8）日本政策投資銀行：『社会資本ストックの生産性効 果』に関する実証研究のサーベイ，地域レポート第 11 号, 2004.

9）長島直樹：社会資本の生産性と公共投資の効率, FRI Review 夏季号 pp.36-43，2000.

10) 浅子和美：政府資本の生産力効果, ファイナンシャ ルレビュー, Vol.26, pp. 97-101， 1993.

11) 吉野直行：公共投資の経済効果，日本評論社，1999

12）三井清 - 大田清: 社会資本の生産性と公的金融, 日本評論社, 1995 .

13）三井清：社会資本整備と地域間スピルオーバー, 研究所年報 (明治学院大学), pp45-62, 2004.

14) Koich Mera:Regional production functions and social overhead capital:An analysis of the Japa -nese case, Regional Science and Urban Economics, Vol. 13, pp. 157-186, 1972.

15）伊多波良雄, 斉藤英則：社会資本ストックと民間資 本ストックの推計, 同志社政策科学研究, pp. 67-90, 1990. 10.

16) 浅子和美, 常木淳, 福田慎一, 照山博司, 塚本隆, 杉浦 正典：社会資本の生産力効果と公共投資政策の経済 厚生評価, 経済分析, 経済企画庁, 第 135 号, pp. 1-87, 1994. 6.

17)榎戸源則：建設会計の講義を, 土木学会誌 話の広 場, Vol. 89, No. 7, pp. 067-068, 2004.7.

18) 土居丈朗:地域から見た日本経済と財政政策, 三菱 経済研究所, 2002.

\title{
Research on Productivity Evaluation of Infrastructure Stock
}

\author{
Ken Koyama, Tatsuo Takase, and Jin Ito
}

Recently, the criticism to public works is severe. Because of aggravation of environmental problems, deterioration of financial picture and problem of holding consultations. Above all, decrease in productivity of infrastructure is the most important. The result of the investment in public works by public works is accumulated as an infrastructure, and contributes to the productivity improvement of the private sector and the improvement of the life environment.

In this research, the effect of the stock for the infrastructure that had already been maintained to bring an economic activity and the improvement at the life of the people for the long term was analyzed. Moreover, this research is focused on the manufacturing efficiency of the infrastructure. 